\title{
The Role of WhatsApp in Teaching Vocabulary to Iranian EFL Learners at Junior High School
}

\author{
Sanaz Jafari ${ }^{1} \&$ Azizeh Chalak ${ }^{1}$ \\ ${ }^{1}$ Department of Foreign Languages, Isfahan (Khorasgan) Branch, Islamic Azad University, Isfahan, Iran \\ Correspondence: Sanaz Jafari, Department of Foreign Languages, Isfahan (Khorasgan) Branch, Islamic Azad \\ University, University Blvd, Arqavanieh, Jey Street, Isfahan, Iran. Tel: 98-31-353-540-019. Fax: \\ 98-31-35-354-060. E-mail: sanazjafari6@gmail.com
}

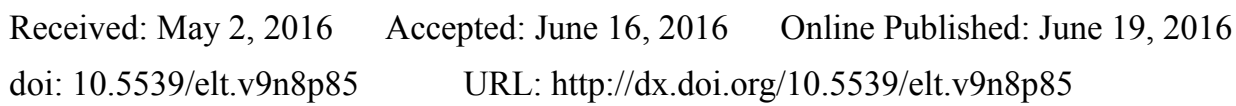

\begin{abstract}
The availability and the use of mobile messaging applications are increasingly widespread among the new generation of students in Iran. The present study aimed to investigate the role of WhatsApp in the vocabulary learning improvement of Iranian junior high school EFL students. Using a mixed method design, a group of 60 students including 30 male and 30 female students studying at two male and female junior high schools in Isfahan, Iran participated in the study. A pre-test and post-test were used. Four English classes were instructed and the experimental group received vocabulary instructions electronically four days a week for four weeks using the WhatsApp while the control group was taught vocabularies of their textbook inside the classroom by traditional method used in all Iranian schools for teaching English to students. The results revealed that using WhatsApp had significant role in vocabulary learning of the students. The results also showed that there was not a substantial difference between male and female students regarding their vocabulary knowledge after using WhatsApp. The findings of this study can be beneficial to Iranian EFL students, teachers, language schools, policy makers, and syllabus designers.
\end{abstract}

Keywords: mobile application, vocabulary, vocabulary knowledge, vocabulary learning, WhatsApp

\section{Introduction}

Using social networks as ancillary tools for students to learn a language better has been studied quite a lot in Iran (Khabiri \& Khatibi, 2013; Yousefzadeh, 2012) and other countries (Blattner \& Fiori, 2009; Stockwell, 2007). Moreover, mobile messaging applications have also been utilized to improve students' progress in learning different language skills and sub-skills consisting vocabulary, pronunciation, grammar, reading and listening (Alsaleem, 2014; Taki \& Khazaei, 2011). Different mobile messaging applications have been examined to be implemented on students, but the effect of WhatsApp on vocabulary learning of Iranian EFL students has not been examined a lot. Also, not many research studies have been done on the effect of gender on vocabulary learning using WhatsApp by Iranians. The problem is that compared to the number of application users who are growing every day, the number of studies conducted on the usage of mobile messaging applications for language learning and teaching is so rare.

Lack of a powerful educational mobile messaging application for use in course books in schools is a great shortage in this century. It means that the energy that the users spend on using these applications is not effectively led to education and learning. By effectively bringing an attractive mobile messaging application like WhatsApp into curriculum of language learning for all the age groups, we can hope that one day in the future a high percentage of learning will happen at homes where learners use these applications.

Adult students who spend long hours in classrooms learning English experience boredom and disinterest (Dong, 2004). They need stimulation to learn vocabulary that could be reinforced by attaching meaning to it (Miramontes, Nadeau, \& Commins, 1997).

Consequently, seeing the need to fill the research gap felt to exist concerning the role of mobile messaging applications in improving L2 learners' vocabulary knowledge in the context of Iran, this study aimed to explore whether WhatsApp had any significant effects on improving Iranian EFL students' vocabulary knowledge. This study also aimed at investigating whether there was a significant difference in using WhatsApp for male and 
female Iranian EFL students.

\section{Literature Review}

Nowadays, in order to be in line with the current trends and changes, the L2 practitioners have to welcome and incorporate the new technology and its vast possibilities (Zhihong, Leijuan, \& Xiaohui, 2010).

Gooniband Shooshtari, Jalilifar, and Khazaie (2013) investigated the effect of the application of mobile devices on teaching English vocabulary items and found that the use of application was successful in the performance of the semi-illiterates. Taki and Khazaei (2011) investigated the use of mobile phone to present vocabulary in written and pictorial forms. The findings showed that the participants who used mobile phone applications performed better when they studied word with pictorial or written annotations. Başoğlu (2010) indicated that the participants who used the mobile application could remember the words better than the ones who used traditional methods. Stickler and Hampel (2010) found that online language course can combine different approaches to learning and teaching, such as using language communicatively and focusing on form and language practice.

Tabatabaei and Heidari Goojani (2012) measured the effectiveness of using mobile phone cheapest applications SMS in teaching L2 vocabulary to Iranian EFL students. Their results showed the effectiveness of using tools related to the students' digital age. Yousefzadeh (2012) examined the superiority of mobile-based collocation words learning in comparison with classical paper-based collocation words learning. The result showed the superiority of mobile-based group over paper-based group.

Chen (2008) investigated the use of mobile phones for the delivery of vocabulary materials to English learners in Taiwan. The results showed that the EFL learners preferred using their phones because of easy access to materials and the ability to practice anytime and anywhere.

Stockwell (2007) concluded that the potential use of mobile applications was great and the learners' vocabulary knowledge was increased due to using the mobile-based intelligent vocabulary application.

Thornton and Houser (2005) examined the use of mobile devices in a language learning context. The results showed that the students evaluated educational materials designed for mobile phones very positively, and that they were able to learn via this medium. The researchers also found mobile phones are very effective platforms for vocabulary learning as they are able to draw the students' interests and create new study opportunities.

A lot of researchers (Grant \& Rong, 1999; Wong, Lam, \& Ho, 2002) attempted to explain that gender differences play an essential role in L2 academic achievement. Not only the social context but also gender, as an individual factor, determines significant difference in failure or success in learning of an L2 (Catalán, 2003). Gender may influence the success of L2 learner, but it cannot be constantly predictable (Bidlake, 2005). Regarding vocabulary learning, several ideas revolve around the performance of the two genders. Some studies (Geiger \& Litwiller, 2005) attempted to explain that males have better memory of words and their meanings. However, Gurian and Ballew (2003) believe that, the majority of females' brains develop earlier and faster than males, so it makes females attain complex verbal skills earlier than males. Accordingly, some researchers (Anderson, 2001; Lowe, Mayfield, \& Reynolds, 2003) emphasize on the fact that females' verbal and language tasks are better than those of males. The purpose of Salamat and Pourgharib's (2013) study was to improve the speaking knowledge of EFL students through using mobile phones. The participants were 40 male and female EFL learners aged 18-25. The results showed that the participants who had benefited from mobile-assisted learning had a significantly better performance on a speaking post-test than the participants in the control group.

On the other hand, some other researchers claim that the performance of the memory of males and females has no difference (Hyde \& Grabe, 2008).

In addition, several studies have attempted to explore the difference between male and female L2 learners' strategies in reading comprehension (e.g., Chavez, 2001; Young \& Oxford, 1997), listening comprehension (e.g., Bacon, 1992), and other L2 skills.

The fact is that not many studies have targeted the role of WhatsApp on Iranian vocabulary improvement of Iranian EFL students. The present study will answer the following questions: Does WhatsApp have significant role in improving Iranian EFL junior high school students' vocabulary knowledge? Is there any significant difference in using WhatsApp to improve vocabulary for male and female Iranian EFL junior high school students?

\section{Methodology}

\subsection{Participants}

The participants in this study were 60 students including 30 male and 30 female students. The students aged 14 . The participants' native language was Persian. All of the participants were learning English as their foreign 
language. The participants' English level was elementary. Random sampling procedure was carried out in two junior high school in Isfahan, Iran during the second semester of the 2014-2015 (Iranian academic year). In order to conduct the study, the true experimental design was used. The students were assigned to two experimental and control groups.

\subsection{Instruments}

The instruments employed in this study were pre-test and post-test. Bachman and Palmer's (1996) framework was followed in order to develop a good and reliable pre-test. The present test was designed to test the elementary EFL students' knowledge of vocabulary. The function of the test was prognostic and it was a language proficiency type. The test consisted of just one section namely vocabulary. It consisted of 35 multiple-choice items. The test content was checked against the table of specifications, adequate timing, clarity of instructions, arrangement of items, and feasibility of test administration. The test was given to 20 students similar to the main participants of the study at Javan language institution, Isfahan, Iran to identify mistakes and defective leads and choices in the test. To ensure maximum test reliability it was tried to provide a good testing condition by giving adequate time, answering all the questions before administering the main test, and preventing them from cheating. To determine objectively the characteristics of the individual items, items were inspected in terms of facility level (IF) and discrimination power (ID). The pre-test item facility was $31 \%$ which was considered worthy to use. For item discrimination power, there might be no absolute rule for acceptable and unacceptable ID indices. However, the IDs were higher than $30 \%$, which were considered to be good items. To estimate reliability of the test, Cronbach's formula of reliability measure was employed. The reliability estimate for the test turned out to be 0.77 which is a moderately high index of reliability.

The similar version of pre-test with different item arrangement as well as option arrangement was used as post-test, after implementing the treatments of the study in order to detect the lexical achievement of the participants.

\subsection{Treatment}

The experimental group (EG) installed WhatsApp on their cell phones, tablets or laptops and they electronically received vocabulary instructions four days a week for four weeks (16 sessions). In each session, five vocabulary items were taught to students. All students in the EG were the member of the same WhatsApp chat group. The instructional materials initially available in the print form were developed and converted into a mobile-based format. Different related pictures and videos were also sent to the students which conveyed the meaning of the new words and help the students with the pronunciations. Definitions, synonyms and antonyms of the new words were also practiced in different sentences by using WhatsApp. They also received different drills to practice the new vocabulary items. Teacher asked the students to answer the questions individually and send their answers to the teacher. In other words, the instructional module consisted of three different phases including the pre-teaching phase, the teaching phase, and the post-teaching phase; in pre-teaching phase, based on students' text book, information was provided for the learners. In teaching phase, during each school day, the students were asked to use WhatsApp to learn new vocabulary items, and in post-teaching phase, the learners' vocabulary achievement was measured by post-test.

\subsection{Data Collection and Analysis Procedures}

The data collection procedure was carried out in quantitative phase. The selected participants were divided into two groups: control group (CG) and experimental group (EG). The selected participants in two groups took the pre-test in order to evaluate their vocabulary knowledge which took 35 minutes. The EG installed WhatsApp on their cell phones, tablets or laptops and they electronically received vocabulary instructions The participants in the CG were taught vocabularies of their textbook inside the classroom and repeated, practiced, and did the exercises in the book by traditional method used in all Iranian schools for teaching English to students. And the participants in the EG were taught the same vocabularies via the use of WhatsApp and practiced them by their cell phones, tablets or laptops. The participants in the EG were asked to write a report of their progress after each three sessions.

Item facility index was run to analyze the easiness and difficulty level of items. Independent-sample t-test was carried out twice: once at the very outset of the study (to make sure the control and experimental group participants were at the same level of vocabulary knowledge), and once after the completion of the experiment (to see whether the treatment, using WhatsApp for vocabulary learning had been effective or not). 


\section{Results}

\subsection{Results of the Pre-test}

The mean score of CG and EG was 15.30 and 14.93 with standard deviation of 1.76 and 1.99 , respectively. There was not a statistically significant difference in the vocabulary pre-test scores for the participants in the control and experimental groups $(p=0.45$, Table 1). The mean score of the male and female participants on the vocabulary pre-test was 14.80 and 15.33 with standard deviation of 1.52 and 1.44 , respectively. There was not a statistically significant difference in vocabulary pre-test scores for males and females $(p=0.33$, Table 2$)$.

Table 1. Results of the independent sample t-test for comparing control group and experimental group pre-test scores

\begin{tabular}{|c|c|c|c|c|c|c|c|c|c|c|}
\hline & & \multicolumn{2}{|c|}{$\begin{array}{l}\text { Levene's } \\
\text { Test for } \\
\text { Equality of } \\
\text { Variances }\end{array}$} & \multicolumn{7}{|c|}{ T-test for Equality of Means } \\
\hline & & \multirow[t]{2}{*}{ F. } & \multirow[t]{2}{*}{ Sig. } & \multirow[t]{2}{*}{$\mathrm{T}$} & \multirow[t]{2}{*}{ Df } & \multirow[t]{2}{*}{$\begin{array}{l}\text { Sig. } \\
\text { (2-tailed) }\end{array}$} & \multirow[t]{2}{*}{$\begin{array}{l}\text { Mean } \\
\text { Difference }\end{array}$} & \multirow[t]{2}{*}{$\begin{array}{l}\text { Std. Error } \\
\text { Difference }\end{array}$} & \multicolumn{2}{|c|}{$\begin{array}{l}95 \% \text { Confidence } \\
\text { Interval of the } \\
\text { Difference }\end{array}$} \\
\hline & & & & & & & & & Lower & Upper \\
\hline Pre-test & $\begin{array}{l}\text { Equal } \\
\text { Variance } \\
\text { Assumed }\end{array}$ & .22 & .637 & .753 & 58 & .45 & .36 & .48 & -.60 & 1.34 \\
\hline & $\begin{array}{l}\text { Equal } \\
\text { Variance } \\
\text { not } \\
\text { Assumed }\end{array}$ & & & .753 & 57.12 & .45 & .36 & .48 & -.60 & 1.34 \\
\hline
\end{tabular}

Table 2. Results of the independent sample t-test for comparing male and female's pre-test scores in the experimental group.

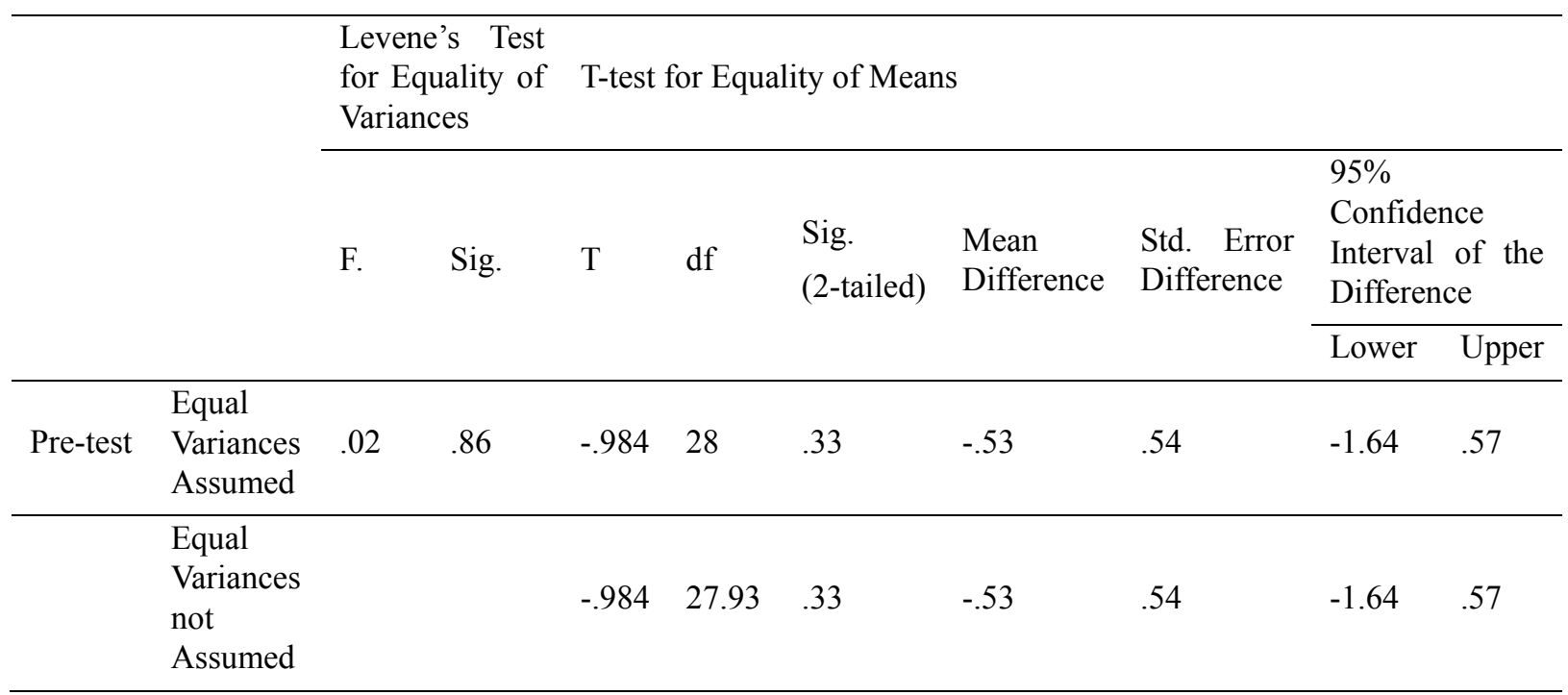

\subsection{Results of the Post-test}

The mean post-test score of CG and EG was 19.23 and 23.93 with standard deviation of 1.99 and 3.66, respectively. There was a statistically significant difference in vocabulary post-test scores for the learners in control and experimental groups $(p<0.001$, Table 3$)$. The mean score of males and females in the CG and EG was 24.53 and 23.33 with standard deviation of 3.75 and 3.59 , respectively. There was not a statistically 
significant difference in vocabulary post-test scores for males and females ( $p=0.37$, Table 4$)$.

Table 3. Results of the independent sample t-test for comparing control and experimental group post-test scores.

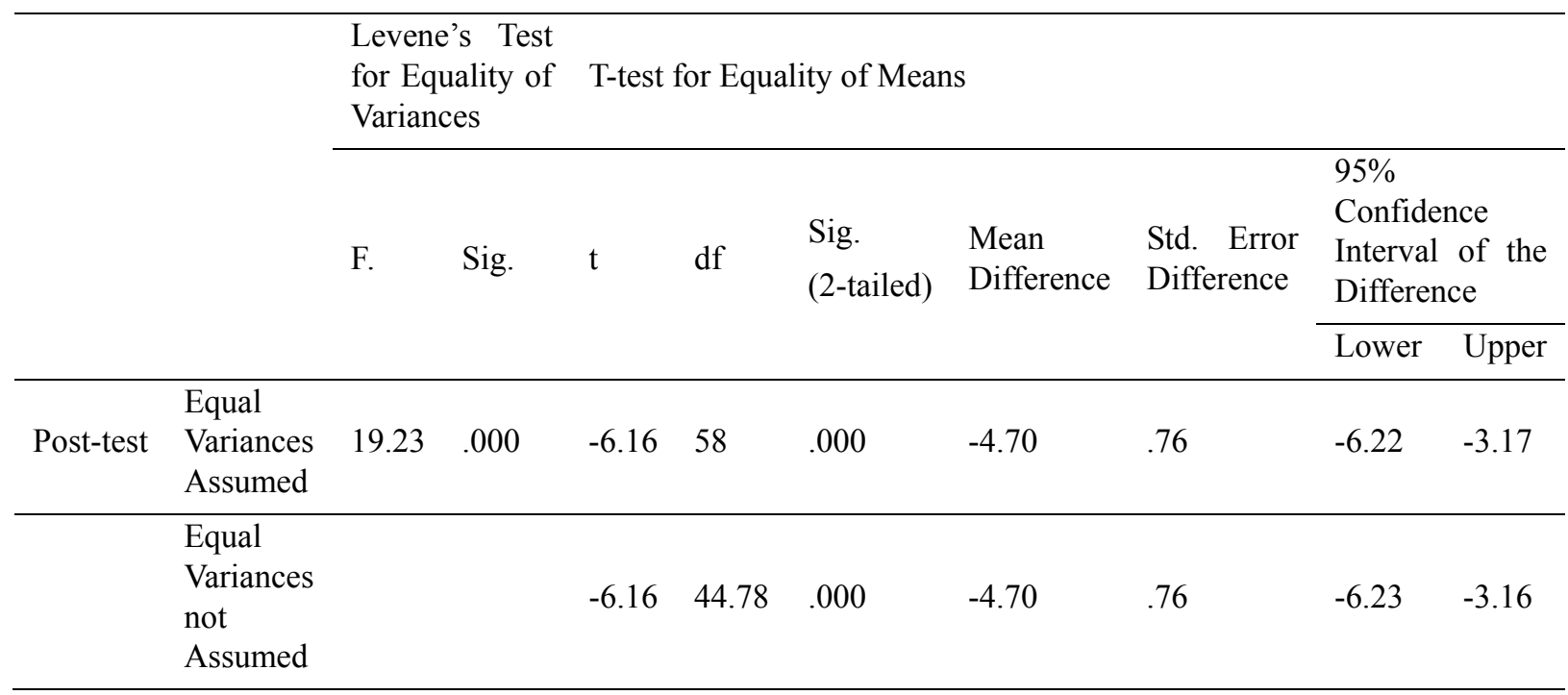

Table 4. Results of the independent sample t-test for comparing male and female's post-test scores in the experimental group

\begin{tabular}{|c|c|c|c|c|c|c|c|c|c|c|}
\hline & & \multicolumn{2}{|c|}{$\begin{array}{l}\text { Levene's Test } \\
\text { for Equality of } \\
\text { Variances }\end{array}$} & \multicolumn{7}{|c|}{ T-test for Equality of Means } \\
\hline & & \multirow[t]{2}{*}{ F. } & \multirow[t]{2}{*}{ Sig. } & \multirow[t]{2}{*}{$\mathrm{t}$} & \multirow[t]{2}{*}{ df } & \multirow[t]{2}{*}{$\begin{array}{l}\text { Sig. } \\
\text { (2-tailed) }\end{array}$} & \multirow[t]{2}{*}{$\begin{array}{l}\text { Mean } \\
\text { Difference }\end{array}$} & \multirow[t]{2}{*}{$\begin{array}{l}\text { Std. Error } \\
\text { Difference }\end{array}$} & \multicolumn{2}{|c|}{$\begin{array}{l}95 \% \\
\text { Confidence } \\
\text { Interval of the } \\
\text { Difference }\end{array}$} \\
\hline & & & & & & & & & Lower & Upper \\
\hline Post-test & $\begin{array}{l}\text { Equal } \\
\text { Variances } \\
\text { Assumed }\end{array}$ & .08 & .76 & .89 & 28 & .37 & 1.20 & 1.34 & -1.55 & 3.95 \\
\hline & $\begin{array}{l}\text { Equal } \\
\text { Variances } \\
\text { not } \\
\text { Assumed }\end{array}$ & & & .89 & 27.94 & .37 & 1.20 & 1.34 & -1.55 & 3.95 \\
\hline
\end{tabular}

\section{Discussion}

By comparing the scores of learners on pre-test and post-test, it was found that using WhatsApp had significantly affected the vocabulary knowledge of the students. The results support those of Gooniband Shooshtari, Jalilifar \& Khazaie (2013) who investigated the effect of the application of mobile devices on teaching English vocabulary items and found that the use of application was successful in outperformance of the semi-illiterates.

The findings of the present study acknowledge those of Başoğlu (2010) who indicated that the participants who used the mobile application could remember the words better than the ones who used traditional methods.

The findings of this study is able to support the results of Stickler and Hampel (2010) who found that online language course can combine different approaches to learning and teaching, such as using language communicatively and focusing on form and language practice.

The results of the present study also support those of Taki and Khazaei (2011) who investigated the use of mobile phone to present vocabulary in written and pictorial forms. The findings showed that the participants who used 
mobile phone applications performed better when they studied word with pictorial or written annotations.

The findings of this study are consistent with those of Tabatabaei and Heidari Goojani (2012) who measured the effectiveness of using mobile phone cheapest applications SMS in teaching L2 vocabulary to Iranian EFL students. The t-test results showed that the students of the experimental group outperformed the students of the control group which shows the effectiveness of using tools related to the students' digital age.

The finding of this study supports those of Yousefzadeh (2012) who examined the superiority of mobile-based collocation words learning in comparison with classical paper-based collocation words learning. The result showed the superiority of mobile-based group over paper-based group.

The results are in line with the findings of Chen (2008) which investigated the use of mobile phones for the delivery of vocabulary materials to English learners in Taiwan. The results showed that the EFL learners preferred using their phones because of easy access to materials and the ability to practice anytime and anywhere.

The findings in the present study regarding the effectiveness of WhatsApp application are in line with Stockwell (2007) who concluded that the potential use of mobile applications was great and the learners' vocabulary knowledge was increased due to using the mobile-based intelligent vocabulary application.

The results are also in agreement with Thornton and Houser (2005) who examined the use of mobile devices in a language learning context. The results showed that the students evaluated educational materials designed for mobile phones very positively, and that they were able to learn via this medium. The researchers also found mobile phones are a very effective platform for vocabulary learning as they are able to draw the students' interests and create new study opportunities.

By comparing the performance of male and female learners on post-test, it was found that there is no significant difference between male and female learners regarding their vocabulary knowledge.This finding is in line with that of Salamat and Pourgharib's (2013) study who investigated the improvement in the speaking knowledge of EFL students through using mobile phones. The results showed that the participants, both male and female, who had benefited from mobile-assisted learning had a significantly better performance on a speaking posttest than the participants in the control group.

\section{Conclusion}

The present research showed that WhatsApp was effective in vocabulary learning of Iranian EFL learners than traditional classroom instructions. Therefore, this study provided some theoretical and pedagogical implications. Developing active language learning environments is a key element for the support of L2 learners, especially for Iranian EFL learners who have difficulty satisfying their language acquisition needs within the limited class hours during their language learning years. To meet this need, social networks and mobile messaging applications like WhatsApp can be integrated into the L2 curriculum purposefully and appropriately, in order to promote learning communities where learners can participate on a regular basis. The findings of this study can be beneficial to L2 pedagogy. The results of the present study help L2 teachers make use of WhatsApp for providing authentic communicative situations for L2 learners. Moreover, the L2 teachers are able to detect the L2 learners' areas of weakness and strength and act accordingly. The L2 learners knowing how to communicate with other L2 learners on WhatsApp can try to do their best to improve their communicative competence.

Mobile applications can bring a wide range of technological possibilities to the class. Language learners also can increase their vocabulary knowledge by simply using WhatsApp. WhatsApp can help the language learners to find the implementation of the words, remember words for longer time, and practice the words after learning.

This study had some limitations. The size of the sample was small and with larger samples we could better analyze the effect of WhatsApp application on students' vocabulary knowledge. Moreover, the participants of the study were elementary EFL learners. They were also non-English major students who study in non-profit schools. Therefore, the range and variety of the participants were also limited.

The findings of this study revealed that WhatsApp improve vocabulary knowledge of the students. WhatsApp needs a lot more research in the field of language learning and teaching especially in Iran. There are many variables and need to be taken under consideration like age, level of proficiency, personality, etc. Further research can be done to investigate the impact of WhatsApp on larger groups of students with different age levels.

\section{References}

Alsaleem, B. I. A. (2014). The Effect of "WhatsApp" electronic dialogue journaling on improving writing vocabulary word choice and voice of EFL undergraduate Saudi students. 21st Century Academic Forum Conference at Harvard Boston, MA U.S.A. Official Conference Proceedings. 
http://www.21 caf.org/uploads/1/3/5/2/13527682/alsaleem-hrd-conference_proceedings.pdf

Anderson, J. (2001). Net effect of memory collaboration: How is collaboration affected by factors such as friendship, gender, and age? Scandinavian Journal of Psychology, 42, 367-375. http://dx.doi.org/10.1111/1467-9450.00248

Bachman, L., \& Palmer, A. (1996). Language testing in practice: Designing and developing useful language tests. Oxford: Oxford University Press. http://dx.doi.org/10.1177/026553229601300201

Bacon, S. M. (1992). The relationship between gender, comprehension, processing strategies, and cognitive and affective response in foreign language listening. Modern Language Journal, 76, 160-178. http://dx.doi.org/10.1111/j.1540-4781.1992.tb01096.x

Başoğlu, E. B. (2010). A comparison of undergraduate students' English vocabulary learning: Using mobile phones and flashcards. Educational Technology, 9(3), 1-7.

Bidlake, E. (2005). Language learning as a gendered experience. Retrieved April 29, 2012, from the World Wide Web: http://research.ncl.ac.uk/ARECLS/volume_4/BIDLAKE.pdf

Blattner, G., \& Fiori, M. (2009). Facebook in the language classroom: Promises and possibilities. Instructional Technology and Distance learning (IDTL), 6(1), 7-28.

Catalán, R. (2003). Sex differences in L2 vocabulary learning strategies. International Journal of Applied Linguistics, 13, 54-77. http://dx.doi.org/10.1111/1473-4192.00037

Chavez, M. (2001). Gender in the language classroom. Boston: McGraw Hill.

Chen, C. H. (2008). Why do teachers not practice what they believe regarding technology integration? Journal of Educational Research, 102, 65-75. http://dx.doi.org/10.3200/JOER.102.1.65-75

Dong, Y. R. (2004). Teaching language and content to linguistically and culturally diverse student. Greenwich, CT: Information Age Publishing.

Geiger, J. F., \& Litwiller, R. M. (2005). Spatial working memory and gender differences in science. Journal of Instructional Psychology, 32(1), 49-57.

Gliem, R. R., \& Gliem, J. A. (2003). Calculating, interpreting, and reporting Cronbach's alpha reliability coefficient for Likert-type scales. Midwest Research-to-Practice Conference in Adult, Continuing, and Community Education.

Gooniband, S. Z., Jalilifar, A., \& Khazaie, S. (2013). Mobile, L2 vocabulary learning, and fighting illiteracy: A case study of Iranian semi-illiterates beyond transition level. Applied Research on English Language, 2(2), 65-79.

Grant, L., \& Rong, X. L. (1999). Gender, immigrant generation, ethnicity, and schooling progress of youth. Journal of Research and Development in Education, 33, 15-26.

Gurian, M., \& Ballew, A. (2003). The boys and girls learn differently. San Francisco: Jossey-Bass.

Hyde, J. Sh., \& Grabe, Sh. (2008). Meta-analysis in psychology of women. In F. L. Denmark, \& M. A. Paludi (Eds.), Psychology of women: A handbook of issues \& theories (pp. 142-174). London: Praeger.

Khabiri, M, \& Khatibi, M. B. (2013). Mobile-assisted language learning: Practices among Iranian EFL learners. European Online Journal of Natural and Social Sciences, 2(2), 176-190.

Lowe, A. P., Mayfield, W. J., \& Reynolds, R. C. (2003). Gender differences in memory test performance among children and adolescents. Journal of Archives of Clinical Neuropsychology, 18(8), 865-878. http://dx.doi.org/10.1093/arclin/18.8.865

Miramontes, O., Nadeau, A., \& Commins, N. (1997). Restructuring schools for linguistic diversity: Linking decision making to effective programs. New York: Teachers College Press.

Salamat, A., \& Pourgharib, B. (2013). The effect of using mobile on EFL students speaking. International Research Journal of Applied and Basic Sciences, 4(11), 3526-3530.

Stickler, U., \& Hampel, R (2010). CyberDeutsch: Language production and user preferences in a Moodle Virtual Learning Environment. CALICO Journal, 28(1), 49-73. http://dx.doi.org/10.11139/cj.28.1.49-73

Stockwell, G. (2007). A review of technology choice for teaching language skills and areas in the CALL literature. ReCALL, 19(2), 105-120. http://dx.doi.org/10.1017/S0958344007000225

Tabatabaei, O., \& Heidari Goojani, A. (2012). The Impact of Text-Messaging on Vocabulary Learning of Iranian 
EFL Learners. CrossCultural Communication, 8(2), 47-55.

Taki, S., \& Khazaei, S. (2011). Learning vocabulary via mobile phone: Persian EFL learners in focus. Journal of Language Teaching and Research, 2(6), 1252-1258. http://dx.doi.org/10.4304/j1tr.2.6.1252-1258

Thornton, P., \& Houser, C. (2005). Using mobile phones in English education in Japan. Journal of Computer Assisted Learning, 21, 217-228. http://dx.doi.org/10.1111/j.1365-2729.2005.00129.x

Wong, K. C., Lam, Y. R., \& Ho, L. M. (2002). The effect of schooling on gender differences. British Educational Research Journal, 28, 827-843. http://dx.doi.org/10.1080/0141192022000019080

Young, D. J., \& Oxford, R. (1997). A gender-related analysis of strategies used to process written input in the native language and a foreign language. Applied Language Learning, 8, 43-73.

Yousefzadeh, M. (2012). Mobile- based learning vs. paper-based learning and collocation words learning. Journal of Educational and Instructional Studies, 2(3), 216-220.

Zhihong, L., Leijuan, H., \& Xiaohui, H. (2010). A research on a student-centered teaching model in an ICT-based English audio-video speaking class. International Journal of Education and Development using Information and Communication Technology, 6(3), 101-123.

\section{Copyrights}

Copyright for this article is retained by the author(s), with first publication rights granted to the journal.

This is an open-access article distributed under the terms and conditions of the Creative Commons Attribution license (http://creativecommons.org/licenses/by/4.0/). 